\title{
Violation of Marine Pollution Laws in Karachi Harbour Became an Environmental Challenge
}

\author{
Muhammad Tahir (Corresponding author) \\ Marine Pollution Law at the Faculty of Law \\ University of Karachi, Pakistan
}

Tel: 03212413488. E-mail: muhammadtahir649@yahoo.com

\author{
Received: January 4, 2017 Accepted: February 24, 2017 Published: March 27, 2017 \\ doi:10.5296/ijssr.v5i1.10555 URL: http://dx.doi.org/10.5296/ijssr.v5i1.10555
}

\begin{abstract}
This article appraises the Factors deteriorating marine environment due to violation of marine pollution laws in Pakistani waters. The environmental degradation of Pakistani waters especially in Karachi coast became a serious threat to the marine environment, marine life as well as human health and marine vessels since long for society. It is determined the level and the distribution pattern of various heavy metals in the coastal waters significantly higher than the standard values. Pollution created by a number of sources is the major contributing factor in this regard. Amongst all, the deteriorating environment in Pakistani waters warrants immediate corrective actions to control Marine Pollution in order to curtail further destruction by this menace. Many steps at Governmental and private level have been initiated however, improvement is a dream. It is rightly to mention that there is no dearth of legislation on the pollution control but implementation of the same by all the concerned agencies and cooperation by public in true letter and spirit is a dream. The prevailing environment cannot be improved without effective enforcement of existing laws in its true perspective by removing all obstacles and difficulties with creating political will of society.
\end{abstract}

Keywords: Karachi harbour, marine environment, violation of laws, implementation of rules, control of marine pollution

\section{Introduction}

As the body requires health to be active and productive, the environment also needs to be healthy in order that it may benefit the living beings on the earth. Polluting the environment is one of the main issues in many developing countries. Some of the developed countries such as US have quite successfully solved the environmental issues by enacting certain laws and 
substitutes for pollutants such as coal and oil power stations have also been provided. Since independence, in Pakistan the pollution issues are at rise beside industrial growth. There is no dearth of legislation on the environmental issues. There may be some issues with the effectiveness in implementation, the awareness among people and the control of land based pollution which becomes the source of marine pollution.

With this premise in mind, this article explores the history of awareness about environmental issues and then the earliest developments of the ideas in the preceding centuries. It is determined the level and the distribution pattern of heavy metals (IAEA Bulletin, 2013) in the coastal waters receiving a continuous discharge of untreated domestic and industrial effluent through Lyari River. (Yukiya, 2013) The presence of all metals (Copper, Iron, Manganese's, Nickle, Led \& Zinc) except for Chormium, in Lyari River and Karachi fish harbour were significantly higher than the standard values. The root causes which lead to the legal frameworks and globalisation of the issue in the $20^{\text {th }}$ century and the legal instruments on which the international environmental law is based. Lastly, the recommendations and the ways to control marine pollution in Pakistani waters is discussed briefly.

\section{Background}

The earth is perhaps the only place in the universe that can sustain human life and the human life is almost dependent on the environment of earth $\&$ its natural resources (Dinah and Alexandre, 2004). The Earth is currently facing lot of environmental concerns. The environmental problems like global warming, acid rain, air pollution, urban sprawl, waste disposal, ozone layer depletion, water pollution, climate change and similar other factors affect humans, animals and other living creatures on this planet. Huge industrialization and marine \& air pollution are causing the weakening of natural assets (FF Conserve Energy Future, 2015). Over the last few decades, the exploitation of our planet and degradation of our environment have gone up at an alarming level. Implementation in true letter \& spirit of relevant laws and regulations are important to solve this problem. Total $70 \%$ of world's oxygen and $80 \%$ of its plants and animal life comes from oceans. (Dr. Geert, 2013) Our globe is more of water than land, hence the oceans \& sea can be called the lungs of the earth. (LoveToKnow Corp, 2013)

\subsection{Definition of Marine Pollution}

Marine environment pollution defined in sec 1(4) of the "Law of the Seas" is "The introduction by man, directly or indirectly of substance of energy into marine environment, including estuaries, which results or it is likely to result in such deleterious effects as harm to the living resources and marine life, hazards to human health, hindrance to marine activities including fishing and other legitimate uses of the sea, impairment of quality for use of sea water and reduction of amenities". (UNCLOS, 1982)

One of the leading scholars of Marine Pollution defined that "In terms of science, marine pollution is defined as change in chemical or physical condition or the biological contents of water in a supply that prevents or limits further use of the water impairs man's aesthetic enjoyment of the water. Aesthetic enjoyment means that only human use of water that allows 
it to be returned to the stream, lake or other source of supply unchanged in quality or quantity”. (Dr. Geert, 2013)

The term marine pollution was defined by United Nations working group called "Group of Experts on Scientific Aspects of Marine Environmental Protection (GESAMP)" in their Reports and Studies No. 47 as "Pollution means introduction by man, directly or indirectly of substances or energy into the marine environment (including estuaries) resulting in such deleterious effects as harm to living resources, hazards to human health, hindrance to marine activities including fishing, impairment of quality for use of seawater and reduction of amenities". (GESAMP, United Nations)

\subsubsection{Types of Pollution}

There are many forms and types of pollution exist according to their nature and effects. However followings are its major types:
a. Oil Pollution
b. Industrial Pollution
c. Organic Pollution
d. Domestic Pollution
e. Land Pollution
f. Ocean Pollution
g. Water Pollution
h. Noise pollution
i. Solid waste
j. Garbage \& Wastes

\subsubsection{Present Condition/Level of Pollution in Karachi Harbour}

The population of Karachi is 9.269 millions as per the national census 1998 which is increasing rapidly day by day and generates solid waste 6,632 tones per day. (PAK-EPA, 2015) The Karachi Harbour, which spreads over an area of around 60sq kms receives diversified pollutants from Land Based as well as Marine Based sources. They include around 280 MGD of untreated industrial cum Municipal water from the city. Operational Wasters from hundreds of fishing crafts in Karachi Fish Harbour, refuse from various industrial and commercial premises situated on the perimeter of the Harbour \& Shipping emissions. These pollutants play havoc with the marine environment and have jeopardized the Marine Ecosystem. Chemical present in industrial effluents cause degradation of hull and machinery of ships in harbour due to their corrosion effects.

\subsubsection{Sources of Pollution}

Karachi generates 472 MGD of wastewater. The capacity of existing sewage treatment plant 
with present working status is charted below:

\begin{tabular}{|l|l|l|}
\hline \multicolumn{1}{|c|}{ Sewerage Treatment Plants } & \multicolumn{1}{c|}{ Optimum Design Capacity } & \multicolumn{1}{c|}{ Actual Treatment } \\
\hline STP-I - SITE & 51 MGD & 20 MGD \\
\hline STP-II - Mehmoodabad & 46.50 MGD & 00 MGD \\
\hline STP-III - Mauripur & 54 MGD & 35 MGD \\
\hline Total & $\mathbf{1 5 1 . 5 0}$ MGD & 55 MGD \\
\hline
\end{tabular}

The above chart shows that out of 472 MGD of the generated municipal effluents only 50 MGD is treated and the rest passes untreated on to the sea through the drains mentioned in section-1. The existing Sewage treatment Plants are operating at reduced capacity due to inadequate transmission capacity of interceptors. (KWSB, 2015)

The prominent drains which transport land-based industrial cum municipal waste to the harbour are as follows:

\begin{tabular}{|ll|l|}
\hline a. & Lyari River & 220 MGD \\
\hline b. & Nehre-e-Khyyam & 16 MGD \\
\hline c. & Soldier Bazaar Nullah & 30 MGD \\
\hline d. & Railway Nullah & 4 MGD \\
\hline e. & Pitcher Nullah & 7 MGD \\
\hline f. & Karli Nullah & 7 MGD \\
\hline
\end{tabular}

\subsubsection{Effects of Pollution on Marine \& Human Life}

According to Constitution of Pakistan 1973 "Every citizen of the country has right to live his life in neat and clean pollution free environment and complete friendly environment can be it existed with the interaction/present of forest and forest/wild life". (Constitution of Pakistan, 1973)

Effects of Marine Pollution are hazardous, very diversified and harm both the human and marine life adversely. As for as Karachi Harbour and its adjoining areas are concerned we have carefully look into the issues of Marine Pollution.

The human life is almost dependent on the environment of earth \& its natural resources. The Earth is currently facing lot of environmental concerns. The environmental problems like global warming, acid rain, air pollution, urban sprawl, waste disposal, ozone layer depletion, water pollution, climate change and similar other factors affect humans, animals and other living creatures on this planet.

a. Effect on Marine Life. The amount of carbon in the water and the atmosphere is continuing to be a problem in the world around us. The oil through many sources washes up on beaches and thus contaminates breeding as well as feeding areas of marine mammals. Skin and eye irritations, blindness, lung and liver failures can be observed on marine life of all types if contact to oil spills over a long period of time. The illnesses among marine animals can occur for years if they directly expose to the toxins found in oil. The oil contaminates can be source of less fertility and decrease birth survival ratio as another adverse affect in marine 
life in the polluted areas.

b. Human Health Issues. The current environmental concerns represent a considerable measure of danger to well-being of people and creatures. Dirty water is the greatest well-being danger of the world and poses a risk to the health and lifespan of people as well as marine animals.

\subsubsection{Chemical Effects of Pollution on Living Elements}

Chemical contamination among plastics, toxins in the wastes like chemicals seep and anti-freeze into the ground is the one of the biggest threats by land pollution to the eco-system. In the recent modern life pattern has invented many chemicals and other un-biodegradable \& unsolvable even after long duration. These material and their particles poison itself the earth where they are dumped. Humans, animals and all other living creatures all are affected by consuming the food etc growing on the same soil due to presence of chemical. This all can be the reason of loss of some types of vegetation/flora and animal life as well as generate long-duration health hazards like cancer in humans. Life cycle/dilution period in sea of different pollutants is given below:

\section{LIFE CYCLE OF DIFFERENT POLLUTANTS IN THE SEA}

(Dr. Geert, 2013)

\begin{tabular}{|c|c|c|}
\hline Ser & Nomenclature & Duration \\
\hline 1. & Paper towel & 02-04 weeks \\
\hline 2. & Banana Peel & 03-04 weeks \\
\hline 3. & Paper Bag & 01 month \\
\hline 4. & News Paper & 1.5 months \\
\hline 5. & Apple Core & 02 months \\
\hline 6. & Cardboard & 02 months \\
\hline 7. & Cotton Glove & 03 months \\
\hline 8. & Orange Peals & 06 months \\
\hline 9. & Ply Wood & $1-3$ years \\
\hline 10. & Wool Sock & $1-5$ years \\
\hline 11. & Milk Cartons & 05 years \\
\hline 12. & Cigarettes Butts & 12 years \\
\hline 13. & Leather Shoes & 40 years \\
\hline 14. & Tinned Steel Cane & 50 years \\
\hline 15. & Foamed Plastic Cups & 50 years \\
\hline 16. & Rubber Boot Sole & $50-80$ years \\
\hline 17. & Plastic Containers & 80 years \\
\hline 18. & Aluminum cane & 500 years \\
\hline 19. & Plastic Bottle & 450 years \\
\hline 20. & Disposable Diapers & 550 years \\
\hline 21. & Monofilament Fishing Line & 600 years \\
\hline 22. & Plastic Bags & 200-1000 years \\
\hline
\end{tabular}




\subsubsection{Effects of pollution on Marine Vessels}

a. Presence of floating pollutants/solid waste and mixture of untreated industrial \& municipal waste is a source of sever marine pollution in Karachi Harbour. Marine vessels and Merchant Crafts operating at Karachi Harbour make use of sea water for cooling of various equipment/machinery, which frequently malfunction/fail due to presence of floating debris/plastic bags and toxic sea water, thus affecting the efficiency and performance of these system significantly. Chemicals present in industrial effluents cause degradation of hull and machinery of ships in harbour due to their corrosion effects. The suspended polyethylene bags have adverse impact once they choke the cooling water intake of operational craft. The craft at time suffer severe damage resulting in their prolonged unavailability to attend the ship's berthing/un-berthing. The delaying ships movement affects other ships and cumulatively tantamount to great economical loss to the Nation.

b. Chemical Reactions. Corrosion can also occur in the presence of moisture, resulting in the chemical corrosion. For example when iron is exposed to moist air, it reacts with oxygen to form rust. The amount of water complex with iron (III) oxide (ferric oxide) varies is indicated here by the letter " $\mathrm{X}$ ". The amount of water present also determines the colour of rust, which may vary from black to yellow to arrange brown. The formation of rust is a very complex process, which is thought to begin with the oxidation of iron to ferrous (Iron "+2") irons and can be described in terms of chemical equations as"

$$
\mathrm{Fe} \longrightarrow \mathrm{Fe}^{+2}+2 \mathrm{e}^{-}
$$

Both water and oxygen are required for the next sequence of reactions. The iron $(+2)$ ions are further oxidized to form ferric (iron “ +3 ”) ions.

$$
\mathrm{Fe}^{+2} \longrightarrow \mathrm{Fe}^{+3}+\mathrm{e}^{-}
$$

The electrons provided from both oxidation steps are used to reduce oxygen as

$$
\mathrm{O}_{2}+2 \mathrm{H}_{2} \mathrm{O}+4 \mathrm{e}-\longrightarrow 4 \mathrm{OH}
$$

The ferric ions then combine with oxygen to form ferric oxide iron (III) oxide which is then hydrated with varying amount of water. The overall equation for the rust formation may be written as:

$$
4 \mathrm{Fe}(\mathrm{OH})+\mathrm{O}_{2} \longrightarrow 2 \mathrm{H}_{2} \mathrm{O}+2 \mathrm{Fe}_{2} \mathrm{O}_{3} \cdot \mathrm{H}_{2} \mathrm{O}
$$

\subsubsection{Mangroves Decay/Deforestation}

Both back water of Karachi harbour houses large forests of Mangroves, which are essential component of the food chain. The toxicity and heavy metals of the industrial effluents retarded the growth of these trees. The mangroves provide diverse habitat for a complex and interdependent community of invertebrates, fish, birds and reptiles. (IAEA, 2013) The primary productivity of these mangrove-covered deltaic areas are four to seven times those of coastal areas without mangroves. Mangroves are woody plants (trees or shrubs) which grow in the topical coastal areas, in the intertidal zone. (Pakistan Marine Academy, 2015) Mangroves provide food to the marine organisms and fish, shrimps, crabs etc. Flourish in the 
mangroves and get their food from them. They need a mixture of freshwater and sea water to flourish. Considering to direct and indirect benefits of mangroves forest, it should be our main priority to protect these forests, for prosperity and well being of people of our country as well as to protect the environment from marine pollution.

\section{Applicable Laws}

The environmental issues first appeared in the Pakistan legal system in late fifties and early sixties in which about seven laws were enacted on environment issues. In mid seventies, the Ministry of Environment was established and the Pakistan Environmental Protection Ordinance 1983 was enacted. From around mid nineties, the courts in Pakistan started taking cognizance of the cases involving environmental and pollution issues. In 1992, Pakistan participated in Earth Summit and thereafter became party to a number of international treaties and protocols on environment. Now, the main and effective legislation on the topic is Pakistan Environment Protection Act 1997 which is being followed effectively for about 20 years. (PEPA, 1997)

\subsection{Problem Statement - Marine Pollution}

According to PEPA 1997, the term 'environment', inter alia, means the land, air and water. Hence the pollution also relates to these three major sources. Water Pollution is a major problem in Pakistan. There are many sources of water pollution in Pakistan, most of which are found in Karachi, being an industrial city.

Despite government policy for filtration and the release it into the sea of industrial waste, several industries release the contaminated water into sea threatening to extinct marine life and polluting the sea-water. Karachi's sewerage is plonked into rivers and ultimately ends up in the sea. The oil spill incident of Tasman Spirit further increased the pollution in the coastal sea area and caused the beach areas unworthy of visit. The incident has also annihilated millions of fishes and ruined the marine life \& ecosystem.

\subsection{The Pakistan Environmental Protection Act, 1997}

The major legislation on environment is Pakistan Environment Protection Act approved in 1997 (after $18^{\text {th }}$ amendment in constitution of Pakistan powers have been transferred to provinces) replacing the Pakistan Environmental Protection Ordinance, 1983. The new Act of 1997, empowered all affected citizens to approach the courts for any environmental damage. Dedicated judicial forum i.e. Environmental Tribunals have also been established at the provincial levels to hear such cases.

It also requires that no person may import hazardous substances of which chemical activity is toxic, explosive, flammable, corrosive, radioactive, cause directly or in combination with other matters, an adverse environmental effect. The Federal and Provincial governments have designated senior civil judges as Environmental Magistrates to take all contraventions punishable in respect of handling of hazardous substances and pollution caused by motor vehicles. The Federal Government had assigned the powers and functions to the Provincial governments. The Provincial Governments have also delegated powers/functions to 
Environmental Protection Agencies and selected powers to the local governments. As a result of the Act 1997, several other enactments at provincial levels, revised rules and regulations such as National Environmental Quality Standards (NEQS, 2001) Govt of Pakistan, Initial Environmental Examination and Environmental Impact Assessments, Environmental Protection Order also came into force(IEE \& EIA, 2000). At present national \& international applicable existing laws/acts to control the pollution on land and in harbour areas of Pakistan are appended below:

\section{TABLE OF LAWS/ACTS}

\begin{tabular}{|c|c|}
\hline Ser & Law/Act \\
\hline 1. & Constitution of Pakistan 1973 \\
\hline 2. & Pakistan Panel Code 1860 \\
\hline 3. & Pakistan Environmental Protection Act 1997 \\
\hline 4. & National Environmental Quality Standards 2001 \\
\hline 5. & Pakistan Merchant Shipping Ordinance 2001 \\
\hline 6. & Pakistan Navy Manual of Pollution Control \\
\hline 7. & Pakistan Maritime Security Agency Act \\
\hline 8. & Pakistan Territorial Water and Maritime Zone Act 1976 \\
\hline 9. & Sindh Environmental Protection Act 2014 \\
\hline 10. & Karachi Port Trust Act 1886 \\
\hline 11. & Ports Act 1908 \\
\hline 12. & The Sindh Local Government Act 2013 \\
\hline 13. & $\begin{array}{l}\text { The Sindh Local Government (Amendment) Ordinance } 1983 \text { (Sindh Ordinance No. II } \\
\text { of } 1983 \text { Government of Sindh) }\end{array}$ \\
\hline 14. & $\begin{array}{l}\text { Karachi Development Authority Order } 1957 \text { (President's Order No. S.1967) and } \\
\text { Second Amendment Ordinance } 1857\end{array}$ \\
\hline 15. & $\begin{array}{l}\text { The Sindh Buildings Control Ordinance } 1979 \text { (Sindh Ordinance No. V of } 1979 \\
\text { Government of Sindh) }\end{array}$ \\
\hline 16. & Factories Act 19-TX4 (Act XXV of 1934) \\
\hline 17. & Fisheries Act 1897 \\
\hline 18. & United Nations Convention on Laws of the Sea 1982 \\
\hline 19. & $\begin{array}{l}\text { International Convention on Oil Pollution Preparedness, Response and Cooperation } \\
1990 \text { (OPRC) }\end{array}$ \\
\hline 20. & International Convention for the Safety of Life at Sea 1974 \\
\hline 21. & $\begin{array}{l}\text { International Convention for the Prevention of Pollution from Ships } 1974 \text { (modified } \\
\text { by the protocol of 1978)" }\end{array}$ \\
\hline 22. & MARPOL 73/78 \\
\hline 23. & Convention on Civil Liability for Oil Pollution Damage (CLC) \\
\hline
\end{tabular}




\section{Conclusion and Recommendations}

The non-implementation of existing laws led to the present deteriorated situation of marine environment in Pakistani waters. Detail study \& scrutiny of these above said laws reveals that there is no deficiency in any of existing laws if implemented in true spirit and purpose of law makers.

The Pakistan Environmental Protection Act and National Environmental Quality Standards although may not be ideally perfect but are fairly comprehensive on the subject of effluent discharge. They may be enforced in letter and spirit with political will by the society.

There is a need to implement the 'polluters pay principle' in true letter and spirit by engaging the stakeholders in the dialogue. (Adnan, 2012)

Preventing the degradation of coastal ecosystems is a collective responsibility, not that of Karachi alone. Nation has to take collective responsibility for marine pollution. The discharge of effluents must be stopped at the source.

Industries are to ensure to treat their wastes before release into the nearby watercourse / sea complying the NEQS, 2001.

\section{References}

Adnan. (2012). Implementation of Polluter Pays Principle In Pakistan's Corporate Legal Regime: A Comparative Analysis with USA and India, ( $\mathrm{PhD}$ diss. International Islamic University Islamabad, 2012).

Dinah, S., \& Alexandre, K. (2004). Judicial Hand Book on Environmental Law By United Nations Environment Programme, (2004, June 30) (Chapter 1, Page III)

Amano, Y. (2013). Protecting Our Marine Environment, IAEA Bulletin, (2013, September 03) (Vol-54)

US Department of Energy. (2015, December 15). FF Conserve Energy Future. Retrieved from http://www.conserve-energy-future.com/ 15-current-environmental-problems.php

Geert, P. (2013). Marine Pollution, Antwerp Maritime Academy Belgium (1st ed.)

LoveToKnow Corp, Burlingame, California, Effects of Ocean Pollution on Marine Life (2013, October 24) Retrieved from http://greenliving.lovetoknow .com

United Nations Convention on the Law of the Seas (UNCLOS), 1982.

Group of Experts on Scientific Aspects of Marine Environmental Protection (GESAMP), United Nations

Pakistan Environment Protection Agency, Present condition/level of pollution in Karachi harbour, (2015, November 11) Retrieved from www.environment.gov.pk

Karachi, W., \& Sewerage, B. (2015). Sources of Water Pollution. Retrieved from www.kwsb.gos.pk 
IAEA Bulletin 54. (2013, September 03).

Pamphlet of Pakistan Marine Academy. (2015, October).

Pakistan Environmental Protection Act. (1997).

National Environmental Quality Standards. (2001).

Review of Initial Environmental Examination (IEE)/Environmental Impact Assessment (EIA) Regulations. (2000).

\section{Copyright Disclaimer}

Copyright for this article is retained by the author(s), with first publication rights granted to the journal.

This is an open-access article distributed under the terms and conditions of the Creative Commons Attribution license (http://creativecommons.org/licenses/by/3.0/). 